\title{
Energy Efficiency and Indoor Air Quality of Seminar Rooms in Older Buildings With and Without Mechanical Ventilation
}

\section{Energieeffizienz und Raumluftqualität von Seminarräumen im Altbau mit und ohne mechanische Belüftung}

\author{
Stefan Maas ${ }^{1}$, Joël Da Cruz Antunes ${ }^{1}$, Georges Steffgen ${ }^{2}$ \\ ${ }^{1}$ University of Luxembourg, Faculty of Science, Technology and Communication, 6 Rue Coudenhove- \\ Kalergi, L-1359 Luxemburg \\ ${ }^{2}$ University of Luxembourg, Faculty of Language and Literature, Humanities, arts and Education, 11 \\ Porte des Sciences, L-4366 Esch-sur-Alzette
}

\begin{abstract}
The present paper reports on an experimental study performed in a seminar room of the University of Luxembourg in a building of the 1970ies without a major renovation. This lecture room is typical for this building period and has a capacity of 60 seats. It is equipped with a mechanical ventilation system that is normally in operation on workdays for 11 hours a day in semester periods (8:00-19:00h), while windows can be opened manually. A Blower-Door-Test revealed that the room is not airtight. During a year, the ventilation system was shut "on" and "off" in periods of some weeks and the consumed finalenergy was measured, as well as the indoor climate assessed by physical and psychological measurements. For instance, the measured $\mathrm{CO} 2$ concentrations are marginally better with the ventilation system "on", which was not perceived in any way by the occupants during the investigations. It was not possible to properly identify the impact of ventilation on the consumed heat-energy, as the room could not be thermally separated from the rest of the building. But with the system "on" there was a clear increase in consumed primary energy due to the electric consumption of the fans. No relationship between the perceived percentage of dissatisfied and perceived climate could be observed. It is concluded that the typical normal operation modus is questionable for seminar rooms in older buildings with variable occupancy and that a simple shut down or semi-automatic user controlled modus by lowcost retrofit seems advantageous.
\end{abstract}

Keywords: indoor climate, mechanical versus natural ventilation, thermal comfort, indoor air quality, PMV, PPD, seminar rooms in older buildings

\section{Zusammenfassung}

Das vorliegende Artikel berichtet über eine experimentelle Studie, die in einem Seminarraum der Universität Luxemburg in einem Gebäude der 1970er Jahre ohne größere Renovierung durchgeführt wurde. Dieser für diese Bauzeit typische Hörsaal hat eine Kapazität von 60 Plätzen. Es ist mit einer mechanischen Lüftungsanlage ausgestattet, die in den Vorlesungszeiten ("8:00-19:00 Uhr") an Werktagen in der Regel 11 Stunden täglich in Betrieb ist, während Fenster manuell geöffnet werden können. Im Rahmen eines Blower-Door-Tests wurde festgestellt, dass der Raum nicht luftdicht ist. Während eines Jahres wurde die Lüftungsanlage in Zeiträumen von einigen Wochen "ein- und ausgeschaltet" und die verbrauchte Endenergie sowie das Raumklima durch physikalische und psychologische Messungen gemessen. So sind beispielsweise die gemessenen CO2-Konzentrationen bei eingeschalteter Lüftungsanlage etwas besser, was von den Insassen während der Untersuchungen in keiner Weise wahrgenommen wurde. Die Auswirkungen der Lüftung auf die verbrauchte Wärmeenergie konnten nicht eindeutig identifiziert werden, da der Raum nicht thermisch vom Rest des Gebäudes getrennt werden konnte. Aber mit eingeschaltetem System kam es zu einem deutlichen Anstieg des primären Energieverbrauchs aufgrund des elektrischen Bedarfs der Ventilatoren. Es konnte kein Zusammenhang zwischen dem wahrgenommenen Prozentsatz des unzufriedenen und des 
wahrgenommenen Klimas festgestellt werden. Es wird die Schlussfolgerung gezogen, dass der typische Normalbetrieb für Seminarräume in älteren Gebäuden mit variabler Belegung fragwürdig ist und dass ein einfacher Shutdown oder ein halbautomatischer benutzergesteuerter Modus durch kostengünstige Nachrüstung vorteilhaft erscheint.

\section{Stichwörter: Raumklima, mechanische gegenüber natürlicher Lüftung, thermischer Komfort, Raumluftqualität, PMV, PPD, Seminarräume in Altbauten}

\section{Introduction}

Many seminar rooms in schools, universities, and offices were and are equipped with mechanical ventilation systems, as humans are producing odors, water vapor, and $\mathrm{CO}_{2}$, which have to be evacuated to assure good air quality, but only if the room is entirely occupied. With the increasing age of the buildings, the airtightness of the building itself and of the ducts are decreasing. Furthermore, the occupation rate of typical seminar rooms is strongly variable, i.e. changing from "empty" to "fully occupied", while natural ventilation by opening windows is done on a large scale. Modern systems are controlled by sensors to adapt the volume flow rate to the needs in order to save energy. But in this case, priority has been given to older systems, about 50 years old, whose retrofit of this state-of-the-art technology is not economical or desirable. Those older systems are typically used in a time-controlled "on-off" modus with a fixed volume-flow of $100 \%$ or $0 \%$. But as in addition natural ventilation by window opening is possible and buildings become more and more leaky, analyses were carried out through measurements and surveys on the impact of mechanical ventilation on air quality, indoor climate, and energy consumption. A literature review was also conducted and it was found that the studies did not focus on energy saving through in comparison to natural and mechanical ventilation. Moreover, the studies were not done for a specific former seminar room [1].

Therefore, energy meters for heat and electricity were installed to control the energy flow into a typical lecture room at the University of Luxembourg in an older building and several indoor climate parameters were measured to calculate the Predicted Mean Vote (PMV) according to Fanger [2] or ISO 7730. Last but not least, the occupants were asked about their perceptions of the room climate on a regular basis, while the ventilation system was switched "on" and "off" in time periods of some weeks during a complete year. This one-year-period was chosen to average seasonal influences and periods of lectures and holidays, i.e. to get a holistic view over one year to finally identify typical advantages and drawbacks of mechanical ventilation in seminar rooms with windows in older buildings.

A description of the classroom and measuring instruments is presented at the beginning, followed by the implementation and evaluation of the data. Then, the results are presented and discussed, before a summary and conclusions are formulated.

\section{Description of the seminar room and the assessment methods}

\subsection{The room and its ventilation system}

The seminar room entitled subsequently "C-02" is part of the University of Luxemburg on Campus Kirchberg, which was built in 1975 and has not yet undergone any important renovation. This lecture room is typical for this building, i.e. there are others of the same size and type. It has a capacity of 60 seats and a surface of $108 \mathrm{~m}^{2}(12 \mathrm{~m} \times 9 \mathrm{~m})$ and is equipped with single glazed windows on one small side, which can be opened by the users. A photo of the room is shown in Figure 1(a), while Figure 1(b) shows a fresh air supply under the seats (1) and an exhaust air outlet (2) on the ceiling, i.e. a bottomup piston-type ventilation is installed. 


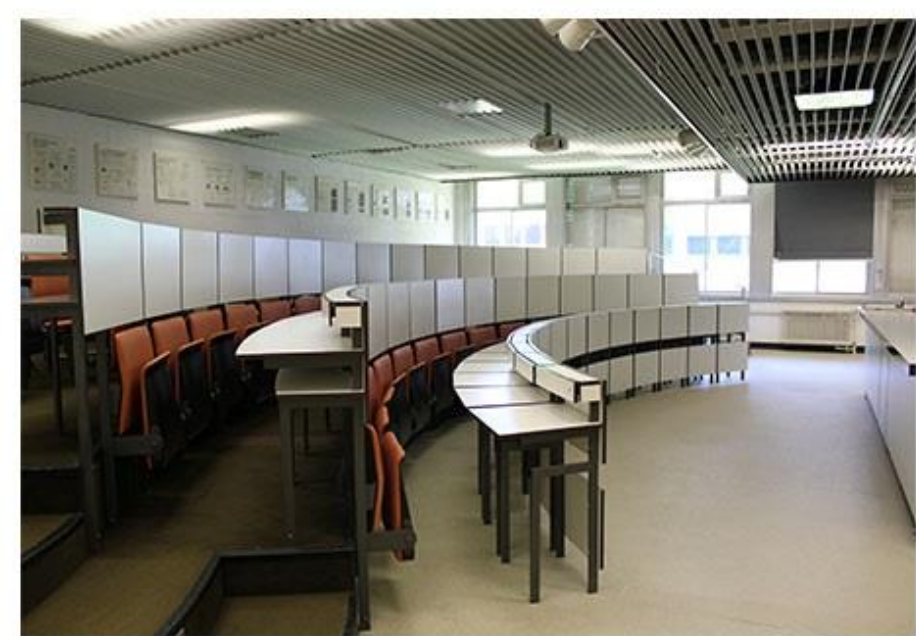

(a) Classroom C-02

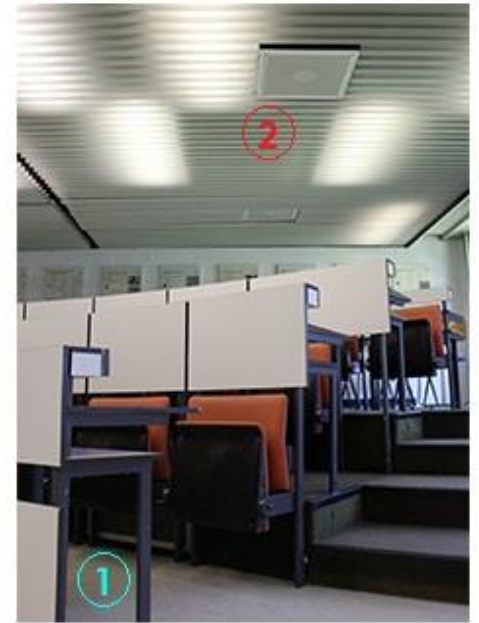

(b) 1 - supply fan of fresh air 2 - return fan of exhaust air

Figure 1: Classroom C-02 of the University of Luxembourg

The incoming fresh air can be heated, humidified and even mixed with the exhaust air after a filtration, i.e. recirculation is technically possible in our system (Figure 2). But neither recirculation nor humidification are used today, i.e. only preheating of supply air is done in winter using a coil fed by heating water with a maximum power of $63 \mathrm{~kW}$. The system has two fans with a nominal volume flow of $4000 \mathrm{~m}^{3} / \mathrm{h}$, while in the final installation with ducts and filters, several measurements were made on all seven outlets and a volume flow rate of $\dot{V}=1740 \mathrm{~m}^{3} / \mathrm{h}$ or $29 \mathrm{~m}^{3} /(\mathrm{h}$.person) was found, corresponding to a typical value according to Roulet [3]. The two fans required together an average of $P=4.2 \mathrm{~kW}$ leading to a Specific Fan Power of SFP=P/V $=2.4 \mathrm{Wh} / \mathrm{m}^{3}$, which obviously corresponds to a very low value [3].

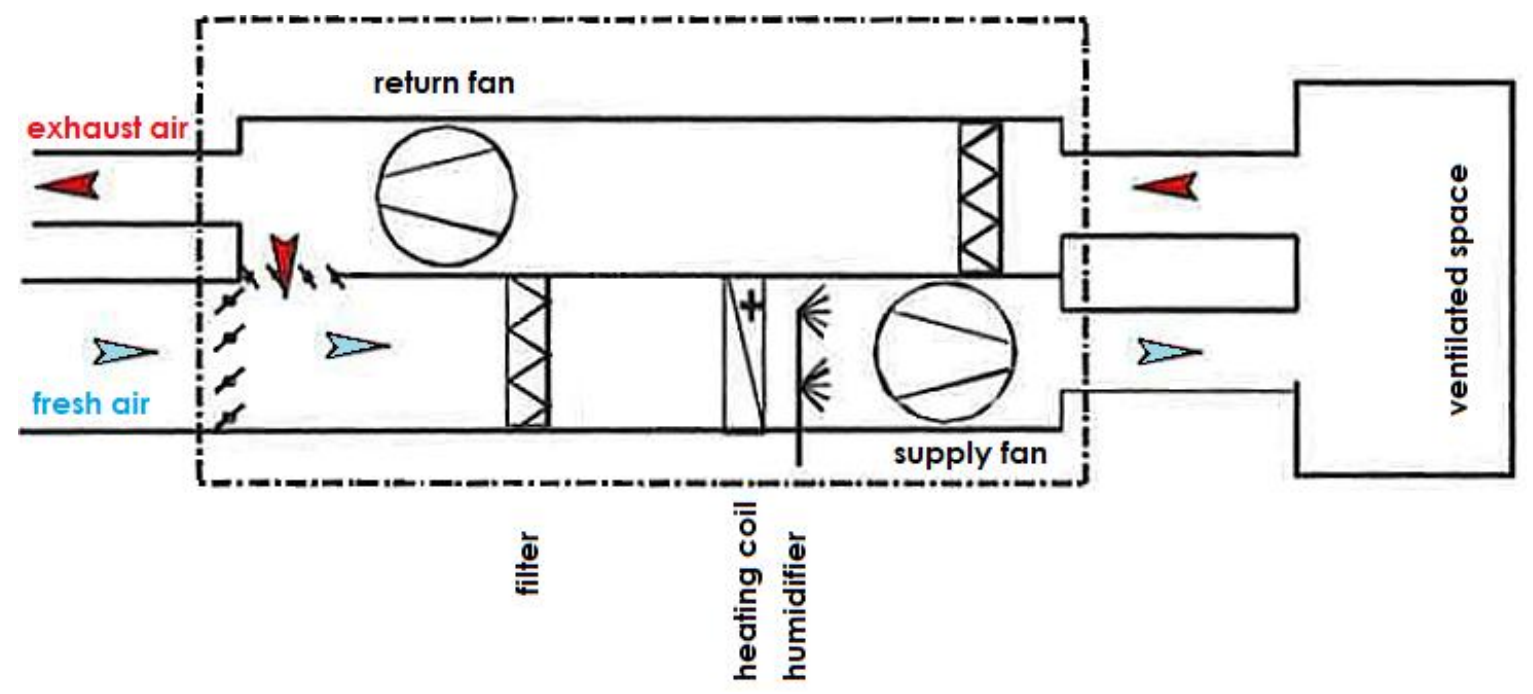

Figure 2: Simplified schematic representation of the ventilation system

Before the start of the experimental study, the airtightness of the seminar room was identified by two blower door tests, while all doors and windows were closed, and the ventilation system was switched off. Once all air inlet and outlet openings are closed with thick plastic sheets and sealed around their circumference with adhesive tape. In this case, the test gave a value of $n_{50}=171 / \mathrm{h}$. In case these openings were not closed, a value of $n_{50}=201 / \mathrm{h}$ was measured. Both values demonstrate the lack of tightness in the seminar room. It was not possible to separate the part of the volume that exited to the outside of the building from the part of the volume that passed through the adjacent rooms inside the building. Therefore, it was concluded that there is inefficient ventilation in a non-airtight room. Nevertheless, this is not uncommon for this type of room and this construction period. 


\subsection{Measurement equipment and measured physical quantities}

Inside our seminar room, the following physical parameters were recorded with the help of two measuring devices: Wöhler CDL 210 [4] and an Ahlborn measuring system [5]:

- carbon dioxide concentration $\left(\mathrm{CO}_{2}\right)$, as an indicator for air quality [3]

- air temperature [3]

- $\quad$ radiation temperature [3]

- relative humidity [3]

- air velocity [3]

All measurements were done in a period of 3 months during the winter season 2012 ( 20 September to 20 December, which is in the following referred as winter semester (ws)) and during the summer season 2013 (21 March to 16 June, which is in the following referred as summer semester (ss)). The measurement frequency was every five minutes.

\subsection{Predicted Mean Vote and measured perceived room climate}

In addition, the users of this seminar-room (our students) were interviewed weekly using a standardized questionnaire, which can be found in the appendix. The type of their clothing, the seating position in the room, the room climate experienced and their satisfaction were recorded and later used to calculate the Predicted Mean Vote (PMV) according to Fanger [2]. The satisfaction with the ventilation-situation and the desire for a change of the indoor climate was asked. The perception of the indoor climate and the noise situation was assessed by subjects on a seven-step scaling, whereby +3 was rated as "very good", 0 as "neutral" and -3 as "very bad". For the satisfaction with the indoor climate, a five-step scale was offered, whereby 1 represented "a complete dissatisfaction" and 5 "a total satisfaction". Requests for changes in temperature, air draft and the perception of light were recorded too, and for control reasons, also the gender and the nationality of the test persons.

In addition, three energy meters were installed to record the consumption of heat (one for the radiators and one for the coil in the ventilation system to preheat the supply air) and electricity used by the fans. Hence all energy flows into this room were measured, except for lighting, and except for uncontrollable air and heat flow from adjacent internal rooms. The weather data of Luxembourg were recorded too and later used to calculate the heating demand of this seminar room.

\subsection{Analysis method}

From the measured physical data, only the daily utilization time (8:00h-18:00h) were considered. The standard DIN EN ISO 7730 [6] was used to determine the PMV (Predicted Mean Vote) according to Fanger [2], with clothing assumed as 1.0 clo corresponding to normal winter office wear [7]. The physical activity was estimated to be 1 met for sedentary activity [7]. Afterward, the PPD (Predicted Percentage Dissatisfied) was determined. The PMV and PPD are directly linked according to Fanger [2].

\section{Results}

\subsection{Air Quality}

In Figure 3 the measured $\mathrm{CO}_{2}$-concentration in the winter semester (ws) is shown. In light green the minimum/maximum values are illustrated, i.e. the five-minutes samples were screened and whenever a trend-change from monotonically decreasing is found (i.e. downwards to upwards), this last value is considered as a minimum (and correspondingly for the maxima). For any period between two extrema, an average is calculated in addition that is shown as a solid red line. The dashed line shows whether the ventilation system was switched "on" or "off" and a typical threshold value (1500 ppm) for "good" and "bad" air quality is also indicated as a solid green line [6]. 


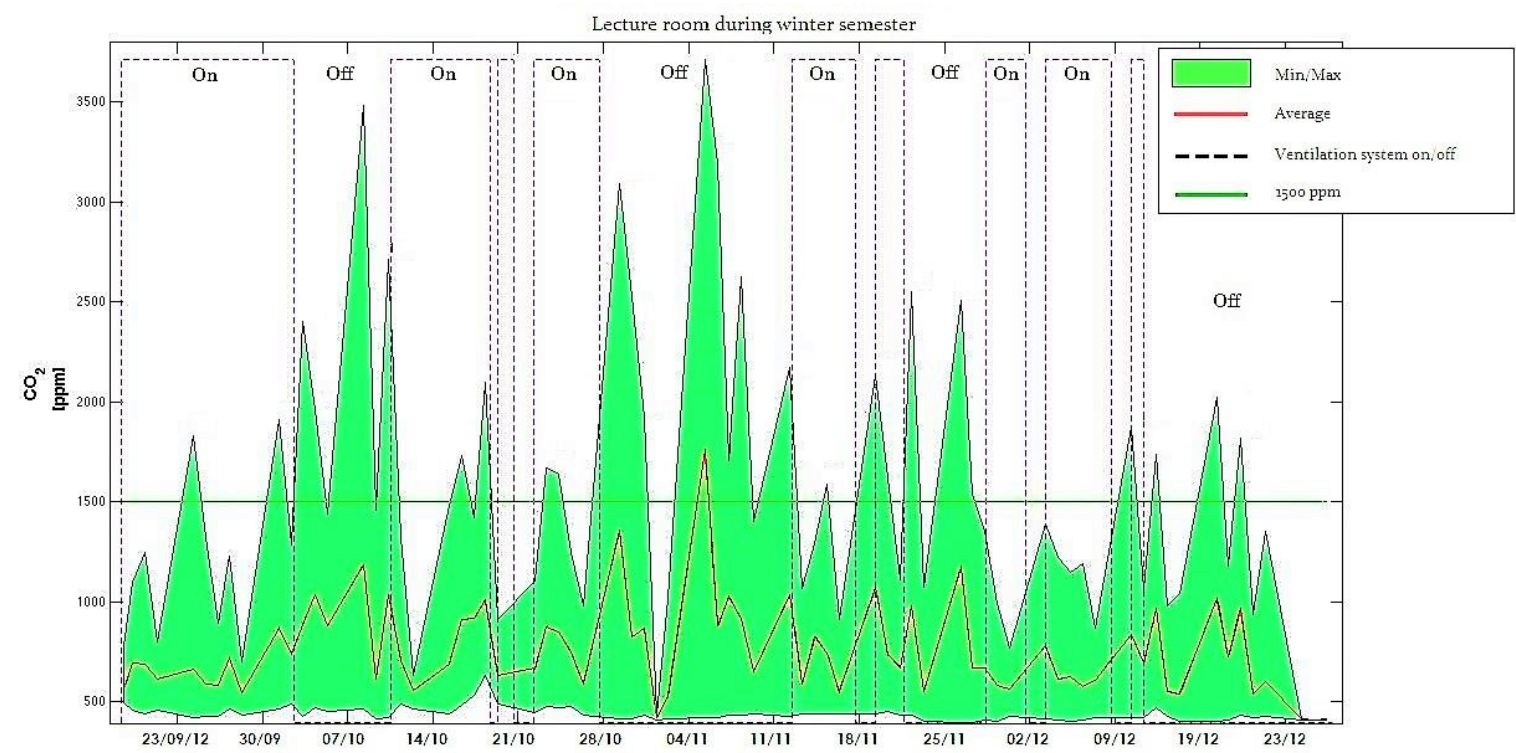

Figure 3: $\mathrm{CO}_{2}$ concentration versus time during the winter semester (ws) and operating periods of the ventilation system.

Based on this figure, it can be seen that natural ventilation (ventilation system "off") the peak values of the $\mathrm{CO}_{2}$ concentrations were higher (up to $3500 \mathrm{ppm}$ ) compared to the periods with the system "on".

With the registered data cumulated frequency diagrams were established (Figure 4), while four intervals were used to classify the measured $\mathrm{CO}_{2}$ concentrations: below $1000 \mathrm{ppm}$ the air quality is considered as "very good" and hence the green color is used. Yellow is selected for 1000 up to $1500 \mathrm{ppm}$, orange for 1500 up to $2000 \mathrm{ppm}$ and red for polluted or used air, i.e. from 2000 to $3500 \mathrm{ppm}$. The winter and summer semesters are indicated as "ws" and "ss".

During the winter semester even with system "off" three-quarters of the time, the air quality is very good and $90 \%$ acceptable, i.e. below $1500 \mathrm{ppm}$. In summer these value increases up to $96.5 \%$, as users open more often the windows. With the ventilation system "on", these values increase in the winter semester to $97.5 \%$ and $100 \%$ in summer.

\section{Distribution of $\mathrm{CO}_{2}$ concentration}

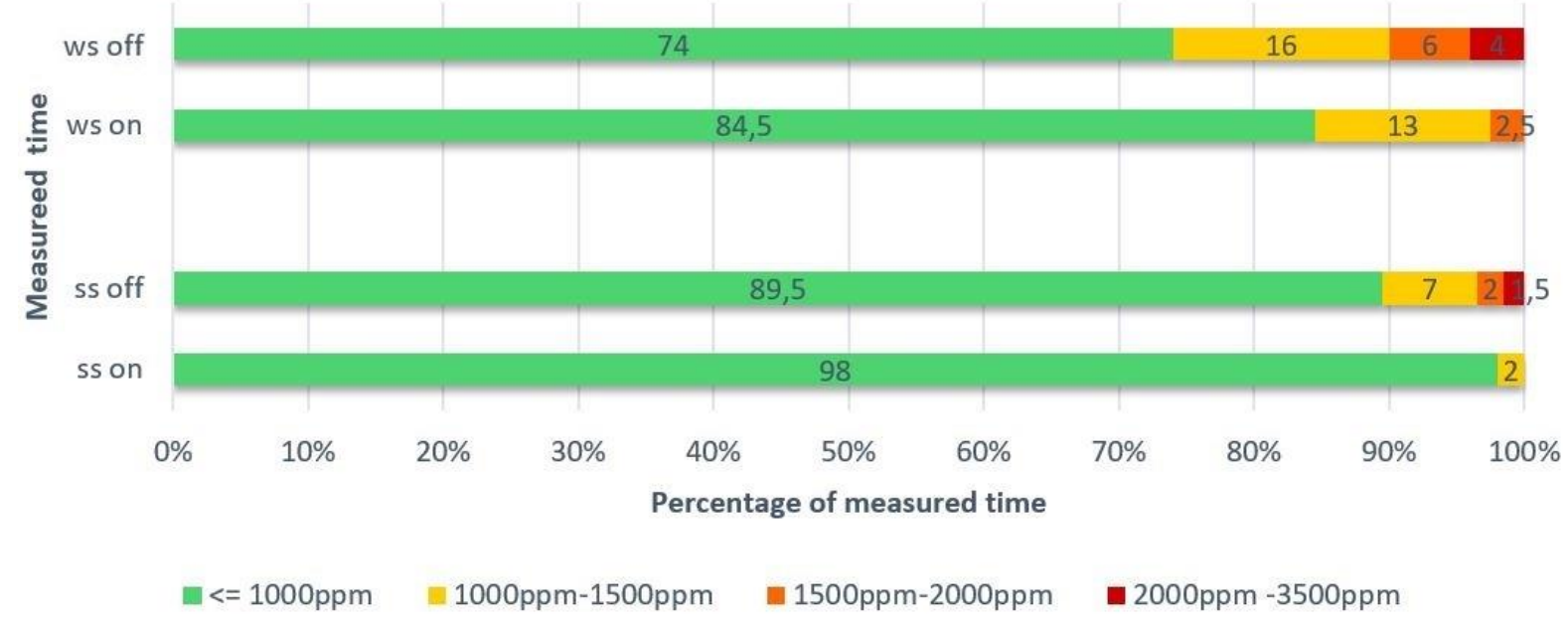

Figure 4: Cumulated frequency diagram of measured $\mathrm{CO} 2$ concentration, classified in 4 intervals and separated for winter and summer semester and ventilation system "on" and "off".

\subsection{Air temperature}


Furthermore, the indoor air temperatures were registered and grouped into four intervals. The cumulated frequency diagrams (ref. to Figure 5) are separated for winter and summer semester and for system "on" and "off".

\section{Distribution of air temperature}

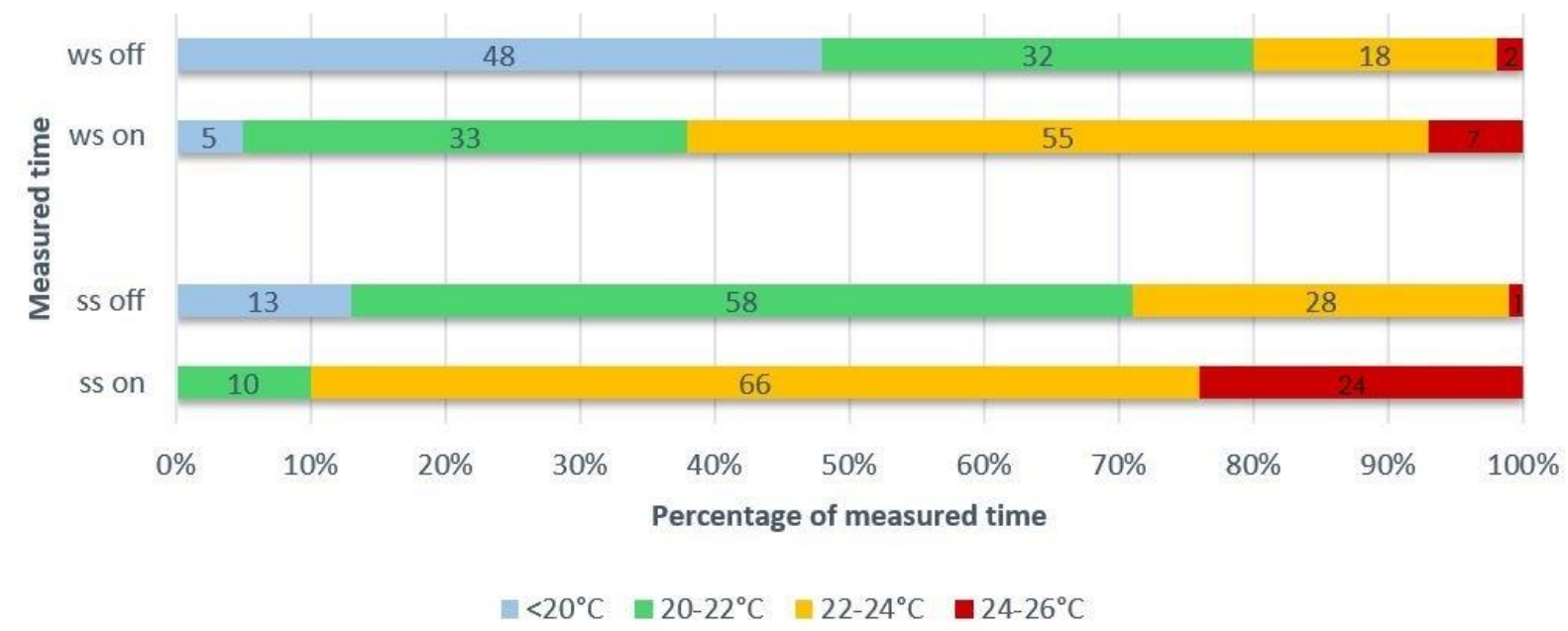

Figure 5: Cumulated frequency diagram of measured indoor air temperature, classified in 4 intervals and separated for summer and winter semester and ventilation system "on" and "off".

It is apparent that the ventilation system with the preheating of the supply air contributes significantly to the heating of this room, before all in the winter season. Without this preheating it is simply too cold $\left(48 \%\right.$ below $\left.20^{\circ} \mathrm{C}\right)$, which is also perceived by the users and detailed later. The heating system must normally be designed and adjusted in such a way that the heating system alone can deliver the necessary energy without the ventilation system and hence not depend on the preheating, i.e. it is a wrong design or adjustment, but not an advantage of the ventilation system as such. With system "on" the air temperature is in winter during $88 \%$ between 20 and $24^{\circ} \mathrm{C}$, i.e. in a normal range. In summer, this range is between $76 \%$ and $24 \%$ of the time above this range, which is normal, as there was no active air conditioning installed in this building.

\subsection{Relative air humidity}

The relative indoor air humidity can be seen in Figure 6 . An acceptable relative humidity is between 30 and $60 \%$, while humans are not very sensitive to this parameter [2]. In winter with the system "on" the air is a bit dryer, which is a known effect and caused by the low absolute humidity outside and the higher air change rate. And in summer, the opposite happens. All measurements are therefore considered normal. 


\section{Distribution of measured relative humidity}

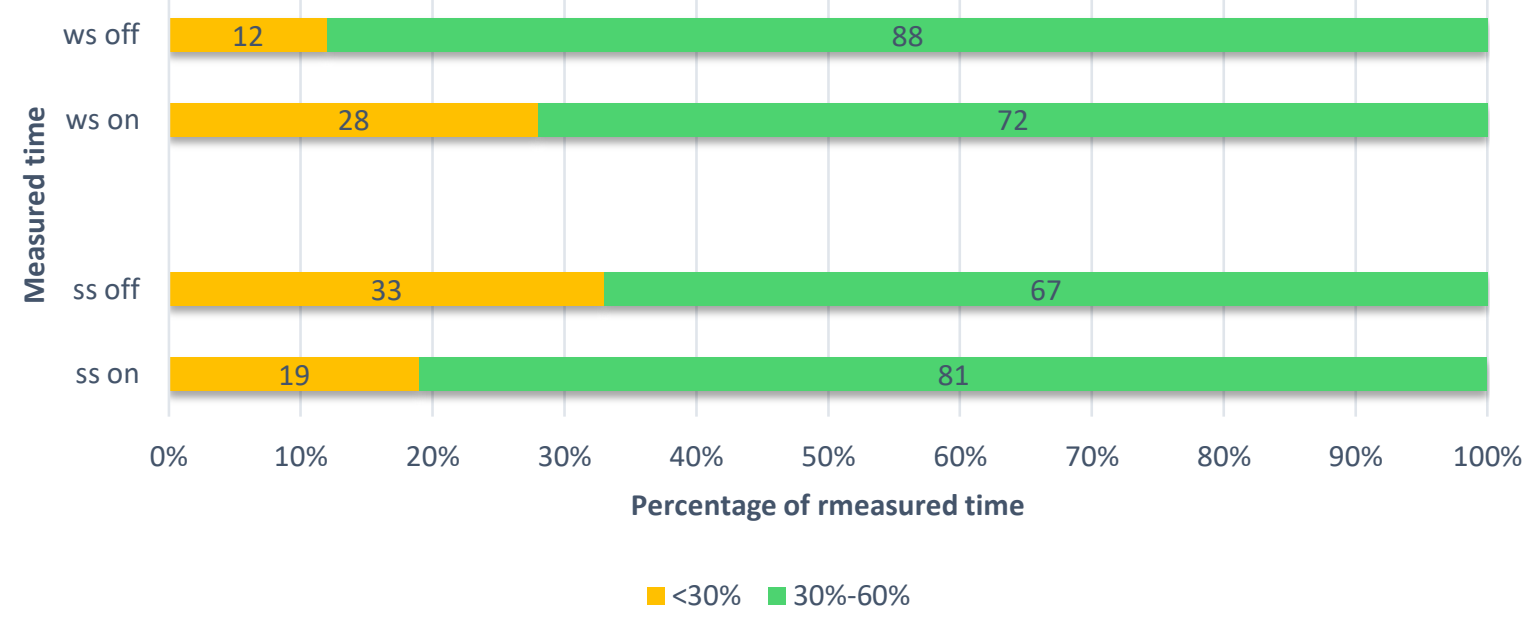

Figure 6: Cumulated frequency diagram of measured indoor air relative humidity, classified in 2 intervals and separated for summer and winter semester and ventilation system "on" and "off".

\subsection{Predicted Mean Vote and Predicted Percentage of Dissatisfied}

The Predicted Mean Vote (PMV) can be calculated according to Fanger [2] by using six different parameters: air temperature, radiation temperature, air speed, relative humidity, insulation level of clothing and physical activity of persons. A perfect comfort leads to PMV equal 0 , while positive values signal that it is too hot and vice versa. If $-0.5 \leq \mathrm{PMV} \leq 0.5$ the comfort is generally considered as "very good" and if $-1.0 \leq$ PMV $\leq 1.0$ it is acceptable, as the number of dissatisfied people is below $20 \%$. The following Table 1 shows the time-weighted averages of the calculated PMV during the lecture period in the winter and summer semester.

Table 1: Mean values for natural and mechanical ventilation per semester.

\begin{tabular}{|l|c|}
\hline & PMV \\
\hline Winter semester ventilation system switched on & -0.4 \\
\hline Winter semester ventilation system switched off & -1.0 \\
\hline Summer semester ventilation system switched on & -0.2 \\
\hline Summer semester ventilation system switched off & -0.4 \\
\hline
\end{tabular}

These PMV values state that it was slightly too cold, especially in winter with the ventilation system switched "off", where the average PMV is below the threshold of -0.5 .

Directly linked to the Predicted Mean Vote (PMV) is the Predicted Percentage Dissatisfied (PPD), the proportion of people in \% dissatisfied with the indoor room climate. The PPD-values were calculated and grouped into 4 intervals. The subsequent cumulated frequency diagrams (ref. to Figure 7) are separated for winter and summer semester and for system "on" and "off". 


\section{Distribution of predicted percentage of dissatisfied}

(PPD)

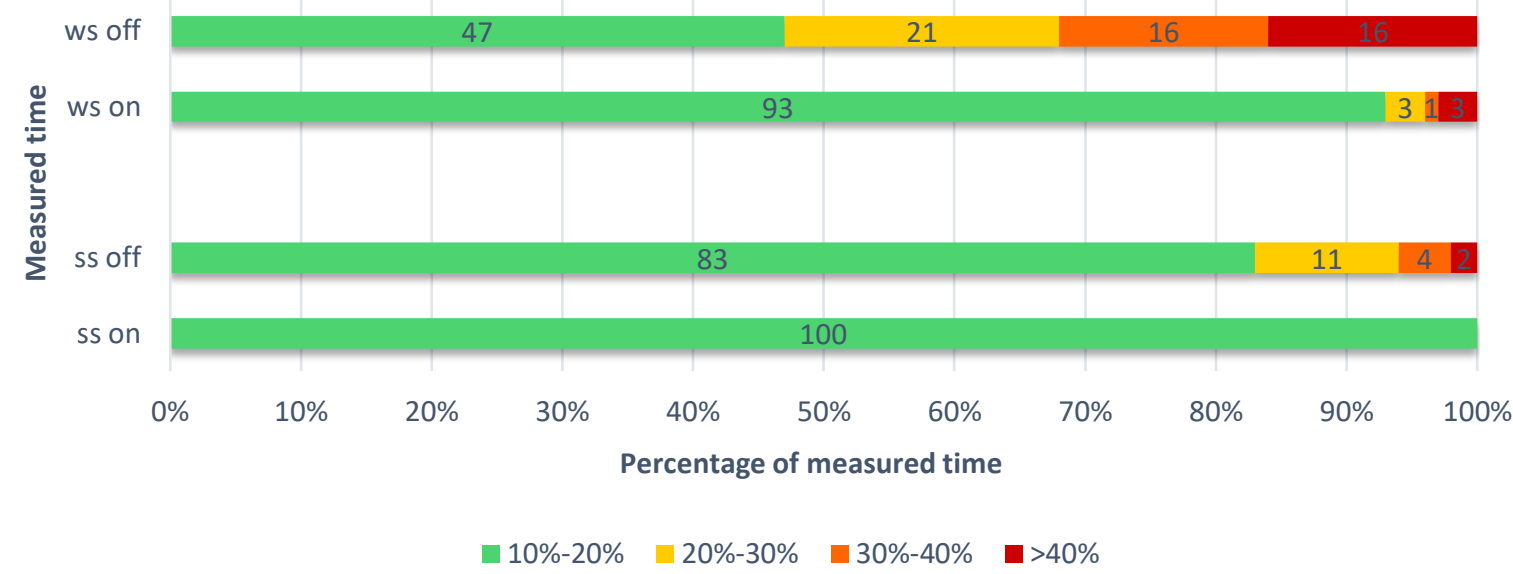

Figure 7: Cumulated frequency diagram of measured PPD-values, classified in 4 intervals and separated for summer and winter semester and ventilation system "on" and "off".

This figure illustrates a big difference between the system "on" and "off". In the latter case, the PPD is significantly higher, as only $47 \%$ are satisfied (PPD $\leq 20 \%$ ). We assumed that this difference was due to the significant contribution of the ventilation system to the heating of the seminar room especially in winter, i.e. without the preheating of the supply air, it was simply too cold in the room. Therefore, the PPD was recalculated using the measured air temperatures from Figure 5 with the ventilation system "on", while the other parameters were used unchanged. This result is shown in Figure 8.

\section{Distrubition of PPD for identical air temperature for each semester}

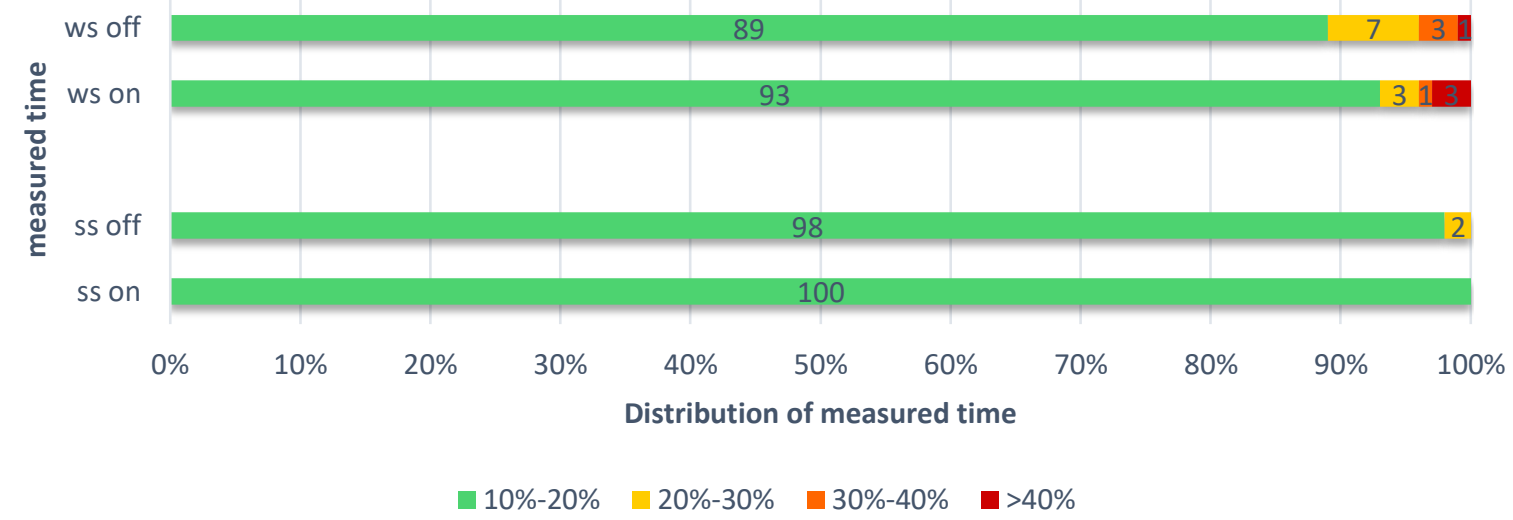

Figure 8: Cumulated frequency diagram of measured PPD-values calculated with air temperatures of the system "on", classified in 4 intervals and separated for summer and winter semester and ventilation system "on" and "off".

Figure 8 shows that with identical air temperatures the differences between system "on" and system "off" almost disappear and in all cases a very high satisfaction was reached.

\subsection{Physical Quantities and perceived comfort and climate}

There were two surveys per week during the winter semester, i.e. after two lectures per week, the students were interviewed in this lecture room C-02 after the respective course, in which a total of 83 persons took part. 
First, questions were asked about the perceived indoor air temperature (blue line) and we compared it to the measured one (red line, ref. to Figure 9). Following the scaling of Fanger, we offered the students a range from -3 to +3 with -3 corresponding to "very cold", 0 for "neither-nor", +3 in case of "very warm". It should be noted that the number of participants decreased during the semester from approximately 30 to 15 and that course two ended already after week 11 .

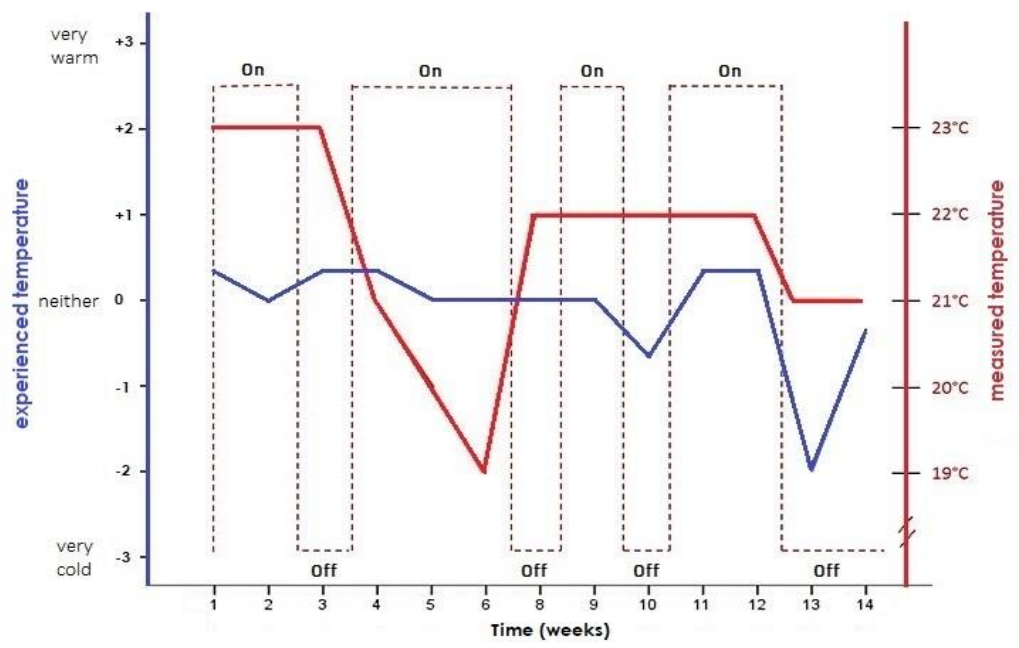

Figure 9: Averages of the perceived (blue line referring to the left vertical axis) room temperature compared to the measured average temperature during the lecture (red line referring to the right vertical axis).

The second question asked referred to the general satisfaction with the indoor climate (Figure 10).

A five-step scale was proposed with "1" corresponding to "complete dissatisfaction" and " 5 " for "total satisfaction". The dashed line of the PPD graph replaces a missing value due to measurement problems that could not be calculated for week 8 .

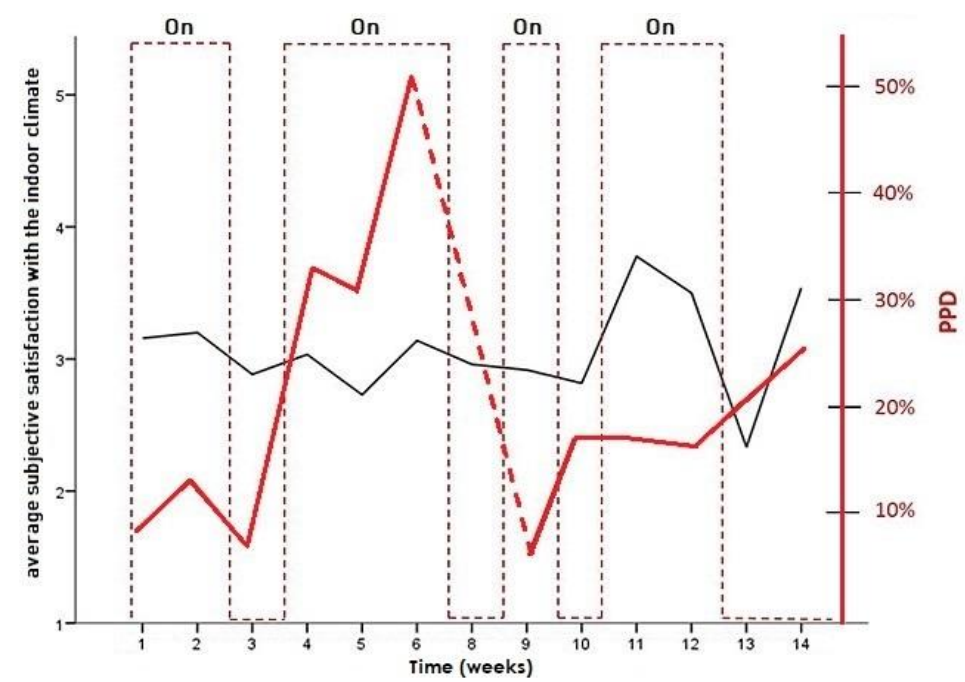

Figure 10: Averages of the perceived satisfaction with the room climate during the lecture period compared to measured $P P D$

Neither from Figure 9 nor Figure 10 a clear relation between the observed human sensitivities and the measured temperature and the PPD can be identified. Furthermore, no relationship with the ventilation system "on" or "off" can be recognized.

\subsection{Energy consumptions}

As already mentioned in paragraph 2.3, the final energy consumption for heating and ventilation of this room was measured by three installed meters. One heat meter for the radiators and a second one for 
the coil to preheat the supply air (Figure 2). Finally, there was an electric meter to register the electric consumption of the two fans. All measured energies are summarized in subsequent Table 2.

Table 2: Measured heat and electric energies

\begin{tabular}{|l|l|l|l|l|l|l|l|l|l|l|}
\hline & Sept. & Octob. & Novem. & Decem. & Jan. & Febr. & March & April & May & $\Sigma$ \\
\hline $\begin{array}{l}\text { Heat radi. } \\
{\left[\mathrm{kWh} / \mathrm{m}^{2}\right]}\end{array}$ & 0.8 & 1.0 & 3.1 & 3.6 & 6.7 & 9.0 & 5.8 & 1.3 & 0.1 & 31.4 \\
\hline $\begin{array}{l}\text { Heat coil } \\
{\left[\mathrm{kWh} / \mathrm{m}^{2}\right]}\end{array}$ & 0.0 & 0.3 & 0.9 & 1.8 & 0.3 & 0.0 & 0.0 & 0.0 & 0.5 & 3.8 \\
\hline $\begin{array}{l}\text { Elec. fans } \\
{\left[\mathrm{kWh} / \mathrm{m}^{2}\right]}\end{array}$ & 2.9 & 2.9 & 2.1 & 1.5 & 0 & 0 & 4.0 & 5.0 & 3.8 & 22.2 \\
\hline $\begin{array}{l}\Sigma \\
{\left[\mathrm{kWh} / \mathrm{m}^{2}\right]}\end{array}$ & 3.7 & 4.2 & 6.1 & 6.9 & 7.0 & 9.0 & 9.8 & 6.3 & 4.4 & $\mathbf{5 7 . 4}$ \\
\hline
\end{tabular}

For the sake of simplicity, we assumed that all electric energy is sooner or later transformed into heat and transferred to the room. This not fully correct, as the energy of the return fan of the exhaust air leaves the building (Figure 2). But due to the simplification, we can add up and find a specific energy consumption characteristic of $57.4 \mathrm{kWh} / \mathrm{m}^{2}$ for this seminar room, which is very low for such an old building [8]. Depending on the year, measurements gave in the years before for this special building values between 200 to $250 \mathrm{kWh} / \mathrm{m}^{2}$, which are typical for this category and this year of construction.

\section{Discussion}

First of all, it should be noted that a significant part of the room's heating energy is supplied by the supply air. Hence, turning off the mechanical ventilation requires adjusting the heating system, which is certainly possible, as otherwise, it is simply too cold (ref. to Figure 5).

Regarding the quality of air, it can be concluded that mechanical ventilation improves it a bit (Figure 4). The air is in general judged acceptable if $\mathrm{CO}_{2}$ concentration is below $1000 \mathrm{ppm}$, which is achieved to $84.5 \%$ in winter and $98 \%$ in summer. The PPD below $20 \%$ indicating satisfied users is in all cases above $89 \%$. It is only improved by a maximum of $4 \%$ by the mechanical ventilation system if the temperatures were identical (ref. to Figure 8). These small differences based on our measured values, lead us to believe that climate measurements perceived by users cannot differentiate between the "on" and "off" system (ref. to Figure 10).

As already mentioned, in winter, the indoor relative humidity is lower with the "on" system as the ventilation rate is higher and the outdoor air is absolutely dry. In summer, the opposite occurs (ref. to Figure 6). But we also know that people are generally not very sensitive to relative humidity, although the recommended range for good comfort is between $30 \%$ and $70 \%$ [2].

The true energetic consumption increase due to mechanical ventilation could not be measured in our study, as the seminar room could not be separated thermally from the rest of the building as the values in Table 2 clearly indicate. Therefore, it makes no sense to separate the "on" and "off" periods. But it is clear from Table 2 that this cost is above $22.2 \mathrm{kWh} / \mathrm{m}^{2}$ of electric energy. Using Luxembourg's conversion factor of 2.67 leads to an increase of $60 \mathrm{kWh} / \mathrm{m}^{2}$ of primary energy for the electricity.

On top are the additional losses due to the additional volume flow of air $\dot{V}=1740 \mathrm{~m} / \mathrm{h}$, even without heat recovery in our quite extreme case. Just to roughly estimate those losses, we divide by the surface of $108 \mathrm{~m}^{2}$ and find $16 \mathrm{~m}^{3} /\left(\mathrm{h} \cdot \mathrm{m}^{2}\right)$. Assuming an average temperature difference just for the winter semester between inside and outside of $17^{\circ} \mathrm{C}$ and of 15 weeks $\cdot 5 \mathrm{~d} /$ week $\cdot 11 \mathrm{~h} / \mathrm{d}=825 \mathrm{~h}$ we find:

$E_{\text {heat }}=\rho_{\text {air }} \cdot C_{\text {air }} \cdot 17^{\circ} \mathrm{C} \cdot 16 \mathrm{~m}^{3} /\left(\mathrm{h} \cdot \mathrm{m}^{2}\right)=76 \mathrm{kWh} / \mathrm{m}^{2}$, which can be converted with a factor of 1.1 (in case of fuel oil or gas in Luxembourg) to $84 \mathrm{kWh} / \mathrm{m}^{2}$ of primary energy. We have to add both primary energies and find additional losses of $144 \mathrm{kWh} / \mathrm{m}^{2}$, though a small part of it is available for heating purposes. Hence the increase of the specific primary energy characteristic is absolutely not negligible.

\section{Conclusion}

This study was done with the intention to assess purely experimentally the impact of mechanical ventilation in a typical seminar room of an approximately 50 -year-old building. This analyzed room (C02) can be considered as a typical room for our university institutions during the same construction period without a major renovation. Three energy meters were installed, indoor comfort parameters were measured and a perceived ambient climate was analyzed to determine the advantages and disadvantages of such a system. 
The blower-door test revealed that the seminar room is not at all airtight due to the $n_{50}$ values of $171 / \mathrm{h}$ resp. $201 / \mathrm{h}$. Technically, it would perhaps have been feasible with tracer-gas to separate which part of the test-volume air flow leaves towards the inside of the building and which part towards the outside. But in practice, the doors are not always closed and those tracer-gas measurements are complex in a large building.

Hence, we conclude that it simply not possible to measure inside an older un-tight building one specific room, as this room cannot be separated from the rest. The single room is neither airtight towards other adjacent inner neighbouring rooms nor is it thermally insulated, i.e. there is a considerable heat transmission by conduction and convection.

In the measured characteristics of the indoor climate, small benefits with the ventilation system "on" that are not perceived by users are detectable. The energy cost is very high, which could even be proven by our incomplete measures. The specific consumption of primary energy increases by about a third. That is why in this type of old building, a simple shutdown of the mechanical ventilation system is recommended for seminar rooms. 


\section{References}

[1] Y. Allab, "Evaluation expérimentale des performances des systèmes de ventilation dans le bâtiment : efficacité de ventilation et confort thermique," HAL, 2018.

[2] P. Fanger, Thermal Comfort - Analysis and Applications in Environmental Engineering, Copenhagen: Danish Technical Press, 1970.

[3] C.-A. Roulet, "Santé et qualité de l'environnement intérieur dans les bâtiments,» Lausanne, Presses polytechnique et universitaires romandes, 2004, p. 200.

[4] "https://www.woehler.de/shop/co2-messgeraet.html," [Online].

[5] Ahlborn, "Produktkatalog 2013 - Almemo-Mesgerät," 2013. [Online].

[6] "Ergonomie der thermischen Umgebung - Analytische Bestimmung und Interpretation der thermischen Behaglickeit durch Berechnung des PMV- und des PPD-Indexes und Kriterien der lokalen thermischen Behaglichkeit ( ISO 7730:2005)," in DIN EN ISO 7730, 2006-05.

[7] "Thermal Environmental Conditions for Human Occupancy," in 55-2010, ANSI/ASHRAE Standard, 2010.

[8] "Verbrauchskennwerte für Gebäude," in VDI 3807-1, 2013.

[9] T. Hoos, Einsparpotenzial und ökonimische Analyse der energetischen Sanierung staatlicher GeBaûde in Luxemburg, Aachen: Shaker Verlag, 2013.

[10] "www.researchgate.net," [Online]. Available: https://www.researchgate.net/figure/Predicted-percentage-dissatisfied-PPD-as-a-function-ofpredicted-mean-vote-PMV_fig1_305755583.

[11] "Ventilation for Acceptable Indoor Air Quality.," in 62.1-2007, ASHRAE Standard, 2007.

[12] "Wirtschaftlichkeit gebäudetechnischer Anlagen - Grundlagen und Kostenberechnung," in VDI 2067, 2012.

[13] "statistiques.public.lu," [Online]. Available: http://www.statistiques.public.lu/stat/TableViewer/tableView.aspx?Reportld=12711\&IF_Lang uage $=$ eng\&MainTheme $=1 \&$ FldrName $=2$. 


\section{Annexe}

Questionnaires used in the surveys:

\section{Your clothing}

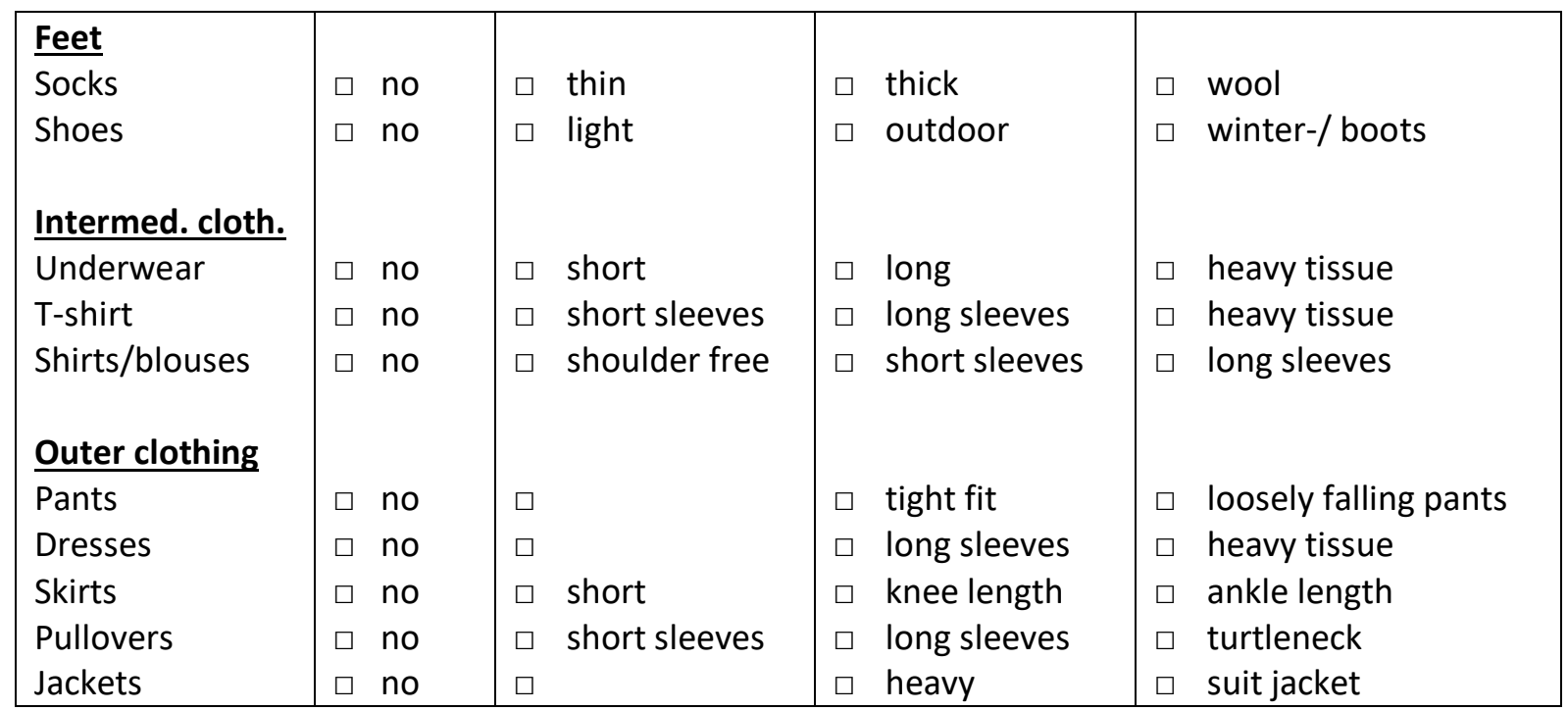

How is your actual mental state, sensitivities?

\begin{tabular}{|l|l|l|l|l|l|l|l|l|}
\hline very good & $\square$ & $\square$ & $\square$ & $\square$ & $\square$ & $\square$ & $\square$ & very bad \\
\hline
\end{tabular}

How do you rate the indoor climate in this seminar room:

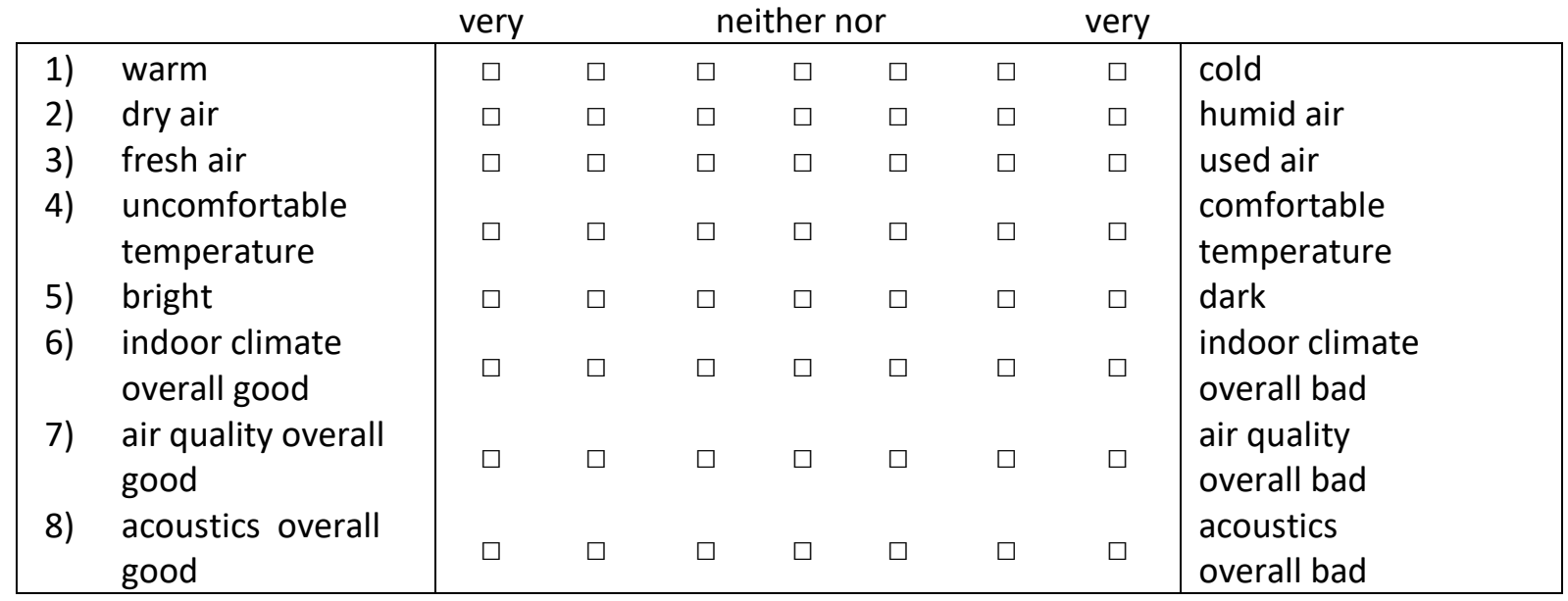

\begin{tabular}{|c|l|ccccc|l|}
\hline 9$)$ & $\begin{array}{l}\text { no draft at all in } \\
\text { the room }\end{array}$ & $\square$ & $\square$ & $\square$ & $\square$ & $\square$ & $\ldots$ very strong draft \\
\hline 10$)$ & $\begin{array}{l}\text { no disturbing smell } \\
\text { in the room }\end{array}$ & $\square$ & $\square$ & $\square$ & $\square$ & $\square$ & $\begin{array}{l}\text {... very disturbing } \\
\text { smell }\end{array}$ \\
\hline 11$)$ & $\begin{array}{l}\text { I would like to turn } \\
\text { off the ventilation } \\
\text { system completely }\end{array}$ & $\square$ & $\square$ & $\square$ & $\square$ & $\square$ & $\begin{array}{l}\text {... to turn on at max. } \\
\text { power the ventilation } \\
\text { system }\end{array}$ \\
\hline
\end{tabular}




\begin{tabular}{|l|l|lllll|l|}
\hline 12) & $\begin{array}{l}\text { I am not satisfied } \\
\text { at all with the } \\
\text { indoor climate }\end{array}$ & $\square$ & $\square$ & $\square$ & $\square$ & $\square$ & $\begin{array}{l}\text {... very satisfied with } \\
\text { the room climate }\end{array}$ \\
\hline 13$)$ & $\begin{array}{l}\text { the indoor climate } \\
\text { is not important at } \\
\text { all for me } \\
\text { personally. }\end{array}$ & $\square$ & $\square$ & $\square$ & $\square$ & $\square$ & $\begin{array}{l}\text { is very important for } \\
\text { me personally }\end{array}$ \\
\hline
\end{tabular}

\begin{tabular}{|c|c|c|c|c|c|c|c|c|c|}
\hline \multicolumn{2}{|c|}{ I would like to have } & \multicolumn{2}{|c|}{$\begin{array}{l}\text { very } \\
\text { much }\end{array}$} & \multicolumn{3}{|c|}{ neither nor } & \multicolumn{2}{|c|}{$\begin{array}{l}\text { very } \\
\text { much }\end{array}$} & \\
\hline 14) & $\begin{array}{l}\text { the temperature } \\
\text { colder }\end{array}$ & $\square$ & $\square$ & $\square$ & $\square$ & $\square$ & $\square$ & $\square$ & warmer \\
\hline 15) & reduce draft & $\square$ & $\square$ & $\square$ & $\square$ & $\square$ & $\square$ & $\square$ & more draft \\
\hline 16) & windows less open & $\square$ & $\square$ & $\square$ & $\square$ & $\square$ & $\square$ & $\square$ & windows more open \\
\hline 17) & less light & $\square$ & $\square$ & $\square$ & $\square$ & $\square$ & $\square$ & $\square$ & more light \\
\hline
\end{tabular}


Prof. Dr. -Ing. Stefan Maas Stefan Maas ${ }^{1}$

Dipl. -Ing. Joël Da Cruz Antunes ${ }^{1}$

Prof. Dipl.-Psych. Georges Steffgen²

${ }^{1}$ University of Luxembourg, Faculty of Science, Technology and Communication, 6 Rue CoudenhoveKalergi, L-1359 Luxemburg

${ }^{2}$ University of Luxembourg, Faculty of Language and Literature, Humanities, arts and Education, 11 Porte des Sciences, L-4366 Esch-sur-Alzette

\section{List of figures:}

\begin{tabular}{|c|c|}
\hline Number & Caption \\
\hline 1 & $\begin{array}{l}\text { Figure 1: Classroom C-02 of the University of Luxembourg } \\
\text { Abbildung 1: Klassenzimmer C-02 der Universität Luxemburg }\end{array}$ \\
\hline 2 & $\begin{array}{l}\text { Figure 2: Simplified schematic representation of the ventilation system } \\
\text { Abbildung 2: Vereinfachte schematische Darstellung der Lüftungsanlage }\end{array}$ \\
\hline 3 & $\begin{array}{l}\text { Figure 3: } \mathrm{CO}_{2} \text { concentration versus time during the winter semester (ws) and operating periods of } \\
\text { the ventilation system. } \\
\text { Abbildung 3: CO2-Konzentration über die Zeit während des Wintersemesters (ws) und die } \\
\text { Betriebszeiten der Lüftungsanlage. }\end{array}$ \\
\hline 4 & $\begin{array}{l}\text { Figure 4: Cumulated frequency diagram of measured CO2 concentration, classified in } 4 \text { intervals } \\
\text { and separated for winter and summer semester and ventilation system "on" and "off". } \\
\text { Abbildung 4: Zusammengefasstes Verteilungsdiagramm der gemessenen CO2-Konzentration, } \\
\text { klassifiziert in } 4 \text { Intervallen und getrennt für Winter- und Sommersemester und Lüftungsanlage } \\
\text { "Ein" und "Aus". }\end{array}$ \\
\hline 5 & $\begin{array}{l}\text { Figure 5: Cumulated frequency diagram of measured indoor air temperature, classified in } 4 \\
\text { intervals and separated for summer and winter semester and ventilation system "on" and "off". } \\
\text { Abbildung 5: Verteilungsdiagramm der gemessenen Raumlufttemperatur, klassifiziert in } 4 \\
\text { Intervallen und getrennt für Sommer- und Wintersemester und Lüftungsanlage "ein" und "aus". }\end{array}$ \\
\hline 6 & $\begin{array}{l}\text { Figure 6: Cumulated frequency diagram of measured indoor air relative humidity, classified in } 2 \\
\text { intervals and separated for summer and winter semester and ventilation system "on" and "off". } \\
\text { Abbildung 6: Verteilungsdiagramm der gemessenen relativen Raumluftfeuchte, klassifiziert in } 2 \\
\text { Intervallen und getrennt für Sommer- und Wintersemester und Lüftungsanlage "ein" und "aus". }\end{array}$ \\
\hline 7 & $\begin{array}{l}\text { Figure 7: Cumulated frequency diagram of measured PPD-values, classified in } 4 \text { intervals and } \\
\text { separated for summer and winter semester and ventilation system "on" and "off". } \\
\text { Abbildung 7: Verteilungsdiagramm der gemessenen PPD-Werte, klassifiziert in } 4 \text { Intervallen und } \\
\text { getrennt für Sommer- und Wintersemester und Lüftungsanlage "ein" und "aus". }\end{array}$ \\
\hline 8 & $\begin{array}{l}\text { Figure 8: Cumulated frequency diagram of measured PPD-values calculated with air temperatures } \\
\text { of the system "on", classified in } 4 \text { intervals and separated for summer and winter semester and } \\
\text { ventilation system "on" and "off". }\end{array}$ \\
\hline
\end{tabular}




\begin{tabular}{|l|l|}
\hline & $\begin{array}{l}\text { Abbildung 8: Verteilungsdiagramm der gemessenen PPD-Werte, berechnet anhand der } \\
\text { Lufttemperaturen, klassifiziert in } 4 \text { Intervallen und getrennt für Sommer- und Wintersemester und } \\
\text { Lüftungsanlage "Ein" und "Aus". }\end{array}$ \\
\hline 9 & $\begin{array}{l}\text { Figure 9: Averages of the perceived (blue line referring to the left vertical axis) room temperature } \\
\text { compared to the measured average temperature during the lecture (red line referring to the right } \\
\text { vertical axis). } \\
\text { Abbildung 9: Mittelwerte der wahrgenommenen Raumtemperatur (blaue Linie bezogen auf die } \\
\text { linke vertikale Achse) im Vergleich zur gemessenen Durchschnittstemperatur (rote Linie bezogen } \\
\text { auf die rechte vertikale Achse) während der Vorlesung. }\end{array}$ \\
$\begin{array}{l}\text { Figure 10: Averages of the perceived satisfaction with the room climate during the lecture period } \\
\text { compared to measured PPD } \\
\text { Abbildung 10: Mittelwerte der wahrgenommenen Zufriedenheit mit dem Raumklima während der } \\
\text { Vorlesungszeit im Vergleich zu gemessenem PPD }\end{array}$ \\
\hline
\end{tabular}

\section{List of tables:}

\begin{tabular}{|l|l|}
\hline Number & Caption \\
\hline 1 & $\begin{array}{l}\text { Table 1: Mean values for natural and mechanical ventilation per semester. } \\
\text { Tabelle 1: Mittelwerte (PMV) für die natürliche und mechanische Lüftung im Semester }\end{array}$ \\
\hline 2 & $\begin{array}{l}\text { Table 1: Mean values for natural and mechanical ventilation per semester. } \\
\text { Table 2: Measured heat and electric energies }\end{array}$ \\
\hline
\end{tabular}

